\title{
Lexical Cohesion and Semantic Relation in the English Texts
}

\author{
Putu Dina Pratiwi \\ English Department, Faculty of Arts - Udayana University \\ [pratiwidina08@gmail.com]
}

\begin{abstract}
This study is entitled Lexical Cohesion and Semantic Relation in the English texts. The aims of this study are identifying the types of lexical cohesion and analyzing the semantic relation found in the texts. The d a t a were taken from five texts with different genres. It contains aspects of life and consists of twelve pages. This study was library research which applied the documentation method to collect the data. The data of this study were analyzed using the qualitative method. The theory applied in this study is cohesion in English that explains the types of cohesion into two; lexical cohesion and grammatical cohesion and analyzing the semantic relation found in the text. The result of the analysis shows a lot of lexical cohesions found in the data such as reiteration. Reiteration consists of repetition, synonym and superordinate. Collocation can be explained by means of; Antonym, the same ordered series, and certain lexical sets. Semantic relation between lexical items in the text that makes the text cohesive was also found in this study.
\end{abstract}

Keywords: Lexical cohesion, Semantic relation, Text, Texture.

\begin{abstract}
Abstrak
Studi ini berjudul Hubungan Leksikal dan Semantik dalam teks bahasa Inggris. Tujuan dari penelitian ini adalah untuk mengidentifikasi jenis kohesi leksikal dan menganalisis hubungan semantik yang ditemukan dalam teks. Data diambil dari lima teks yang memiliki genre yang berbeda. Ini berisi aspek kehidupan yang terdiri dari dua belas halaman. Penelitian ini merupakan penelitian kepustakaan yang menerapkan metode dokumentasi untuk mengumpulkan data. Data penelitian ini dianalisis dengan metode kualitatif. Teori yang diterapkan dalam penelitian ini adalah kohesi dalam bahasa Inggris yang menjelaskan jenis kohesi menjadi dua; kohesi leksikal dan kohesi gramatikal dan menganalisis hubungan semantic yang ditemukan dalam teks.Hasil analisis yang dilakukan menunjukan banyak kohesi leksikal dalam data seperti pengulangan. Pengulangan terdiri dari pengulangan, sinonim dan superordinate. Kolokasi dapat dijelaskan dengan cara; Antonym, seri orde yang sama, dan rangkaian leksikal tertentu. Hubungan semantik antara item leksikal dalam teks yang membuat teks kohesif juga ditemukan dalam penelitian ini.
\end{abstract}

Kata kunci: Kohesi lexical, Hubungan semantic, Texture,Text

\section{Background of the Study}

In our life text is very important for us. A text is best regarded as a semantic unit, a unit not of form but of meaning. Text is used in linguistics to refer any passage, spoken or written, of language whatever length that does form of unified whole as stated by Halliday and Hasan $(1976: 1)$.

A text is related to the cohesiveness of the text itself. It is characterized by coherence as well as cohesion and these sets of linguistic resources are found in every language for linking one part of the 
text to another. Coherence in linguistics is what makes a text semantically meaningful and cohesion is the grammatical and lexical relationship within a text or sentence. Cohesion is the links that hold a text together and give it meaning.

Halliday and Hasan (1976:5) mention that cohesion in text can be achieved through grammatical and lexical cohesions. Grammatical cohesion is a kind of cohesion expressed through relation on grammar which can be divided into four parts; they are reference, substitution, ellipsis, and conjunction. In addition, lexical cohesion is the cohesion expressed through relation on vocabulary which can be divided into two parts: reiteration and collocation. Thus grammatical and lexical cohesion support each other, both of them are parts of sentences and cannot be separated.

The concept of lexical cohesion as one of cohesive devices within a text should be fully mastered especially when interpreting the meaning of a lexeme to show how the sentences are related in form to make the text coherence.

Cohesion is related to the semantic tie within text whereby a tie is made when there is some dependent link between items that combine to create meaning. Cohesion is semantic relation between meanings. The relation is between a word and an expression or phrase and it is realized through lexicogrammatical system. Some forms of cohesion can be realized through the grammar and other through the vocabulary.

Furthermore, it is interesting in analyzing of the types of lexical cohesion and semantic relation in English texts with five different fields since to understand what words often happen and also there are a lot of lexical cohesions and semantic relations occurring in the text.

\section{Problems of the Study}

Based on the background stated above, the problems can be formulated as follows:

a. What types of lexical cohesion are found in the English texts?

b. What semantic relations are found in the texts?

\section{Aims of the Study}

Based on the problems of the study above the aims of study can be formulated as the first is identifying the types of lexical cohesion in the English texts and the second is analyzing the semantic relation found in the texts

\section{Research Method}

The research method of this study covers four points including data source, method and technique of collecting data, method and technique of analyzing data and method and technique of presenting data

\subsection{Data Source}

The data source of this study was English texts taken from internet. The texts as the data source were five texts taken from several website. Those are text talking about Internet from (www.sanjran.wordpress.com), Food from (www.preservearticles.com), Hospitality Industry from (www.essaysamples.blogspot.co.id), Importance of Education from (www.wditorialfragua.com) and The Role of Culture in Promoting Architectural

Identity,(www.researchgate.net). The texts in those websites were chosen as the data source because they contain a lot of variations of lexical items in the text that contain many aspects of the five field mentioned above. 


\subsection{Method and Technique of Collecting Data}

The data were collected by library research method. This method was assisted by some techniques. The first step was downloading the English texts from the internet then reading them carefully in order to get a good understanding of the English texts. The next step was finding out and highlighting the texts that contain lexical cohesion having the meaning of reiteration and collocation. The reiteration can be divided into four classes: repetition, synonymy or near synonymy, superordinate and general word. The collocation can be explained by means of complementary, antonym, converseness, the same ordered series, unordered lexical sets, and certain lexical sets. Finally, identifying the relation between meaning (semantic relation) and the elements in the text and some other elements that ae crucial to the interpretation of it

\subsection{Method and Technique of Analyzing Data}

The collected data in this study were analyzed using the descriptive qualitative method. Qualitative means that the data were described in detail based on the relevant theories of the topic discussion. There were some steps in analyzing the data in this study. First, the data were classified based on the theory of types of lexical cohesion proposed by Halliday and Hasan on their book entitled Cohesion in English (1976). The data were categorized into the elements of lexical cohesion such as; reiteration and collocation. The second is the data analysis was presented descriptively by showing the types of lexical cohesion and semantic relation in the text paragraph because the problems of this study need description of analysis in order to make the text understandable to the readers.

\subsection{Method and Technique of Presenting Data}

The analysis of this study was presented descriptively by standard sentences and explanation to show types of lexical cohesion and semantic relation in the text. Therefore, in order to answer the problems in this study, the reporting the model of analysis is arranged based on two sub chapters which cover reiteration and collocation. Each sub chapter covers all aspects of each type. The second is data analysis of semantic relation in the text to show how the cohesive devices exist to create meaning.

\section{Result and Discussion}

The basic theory applied in this study is the cohesion theory proposed by Halliday and Hasan (1976) in their book entitled Cohesion in English. This theory is very closely related to this study because it is aimed to identify the types of lexical cohesion and analyze the semantic relation in the English texts. Cohesion is partly expressed through grammar and partly through vocabulary. Halliday and Hasan distinguishes the types of cohesion into two; grammatical cohesion and lexical cohesion.

\subsection{Reiteration}

Reiteration is a form of lexical cohesion which involves the repetition of a lexical item at one end of the scale: the use of general word to refer back to a lexical item, the other scale; and a number of things in between the use of synonym, near synonym, super ordinate, or general word.

\subsubsection{Repetition}

According to the definition provided by oxford dictionary, the internet is an arrangement of connected computers, which lets the computer users all over the globe exchange data. At the present time approximately 2.1 billion $(33 \%)$ 
of the total population has accessibility to the internet. The internet is an extraordinary entertainment and learning too that may be utilized in a number of modes to increase the ability of a user to collect information.

(https://sanjran.wordpress.com)

The first data is constructed by three sentences that repeat the same words which are connected with each other. In the first sentence the word computer is repeated twice. Meanwhile, the word internet is repeated in the second and third sentences. The lexical computer in the first sentence is marked by the indefinite article the and also in its second assistance also marked by the definite article the. The word computer means an electronic machine that can store, organize and find information. While internet means an international computer network connecting other networks. Those of words are related since internet can be used if there is a computer as a place to connection. Both of those words have the word class as a noun. Therefore, the three sentences are coherent through lexical cohesive device. This is indicated by the appearance of the word computer in the first sentence and internet in the second and third sentences

\subsubsection{Synonym}

You can_find any type of information on any subject with the help of the_search engines like yahoo and Google.

(https://sanjran.wordpress.com)

The sentence above is identical or has the same referent to each other. The word find is synonymous with the word search. Those words are different in their word class, find is a verb and search is a noun in the sentence analyzed. However, they are identical or have the same referent to each other. The words find and search have the same meaning as an attempt to find especially by looking carefully for it.

\subsubsection{Superordinate}

The human body requires food in order to produce the forces which keep the heart beating, the lungs breathing and the limbs moving. But the discovery of vitamins at the turn of the present century has 'rediscovered' the science of nutrition.

(http://www.preservearticles.com)

The words heart, lungs and limbs in the text above collocate with one another and it can be classified as cohyponym. The reason is that they are included in the same superordinate term namely part of the human body. The word human body is superordinate of the word heart, lungs and limbs. The words heart, lungs and limbs are preceded with the definite article the. Both words belong to the same word class as nouns.

\subsection{Collocation}

Collocation is the term that uses all items in the texts that are semantically related, it is related to the idea or sense of meaning. The analysis of collocation can be seen as follows:

\subsubsection{Antonym}

Now it's the responsibility of the parents, teacher and well-wishers of this world to educate their children to differentiate between the good and the bad. We must all work for the betterment of this world and make it a better place for ourselves and for our coming generations. (https://sanjran.wordpress.com)

The text above the words good and bad in one sentence can be classified as antonym, because they have opposite meaning. Both of those words belong to the same word class as adjectives. The words good and bad are preceded with the definite article the. The word good means high quality or an acceptable. 
While, the word bad means unpleasant; full of problems

\subsubsection{The same ordered series} The early name of internet was ARPANET. The idea grew and progressed to the Internet we have today nobody knows where it might lead us tomorrow.

(https://www.researchgate.net/)

The data above is constructed by two sentences, the words early, today and tomorrow can be classified as collocation. It is a kind of the same ordered series and they are included as related items. Here the words early, today and tomorrow refer to the period of times. Both words belong to the same class as adverbs.

\subsubsection{Certain lexical}

Internet is an extraordinary entertainment and learning too that may be utilized in a number of modes to increase the ability of a user to collect information. You can find any type of information on any subject with the help of the search engines like yahoo and Google.

(https://sanjran.wordpress.com)

The text above consists of two sentences that are semantically related through lexical cohesive devices. It is related by the words internet, information, yahoo and google. Those words can be classified as collocation in which they are considered as certain lexical sets. The word internet is related to the word information since internet gives the ability of user to collect information on any subject with the help of the search engines like yahoo and google. Therefore, the text is semantically related by the occurrence of such lexical pairs in the text.

\subsection{Semantic relation}

The human body requires food in order to produce the forces which keep the heart beating, the lungs breathing and the limbs moving. But the discovery of vitamins at the turn of the present century has 'rediscovered' the science of nutrition.

(http://www.preservearticles.com)

The text above consists of two sentences that express semantic relation to hold to each other. It can be seen the cohesive effect of the text formed by the items human body, heart, lungs, limbs are classified in semantic terms since they have semantic relation to one and another. The words human body are considered to be subordinate of the words heart, lungs and limbs and they are parts of human body.

\section{Conclusion}

Based on the analysis in the preceding chapter, there are some conclusions can be drawn; they are as follows:

The types of lexical cohesion were classified into two forms: the first was reiteration which involved repetition, synonym and super ordinate. The second was collocation which can be divided into complementary, antonym, converseness, the same ordered series, unordered lexical sets, and certain lexical sets. Almost all of lexical items were dominated by repetition since many words were repeated in the text although other lexical items show the same meaning, opposite meaning or super ordinate. However, all lexical items support the cohesiveness of text.

The semantic relation of lexical items could be found in the relation between the lexical items that had identity of reference. The coherence of the text helped cohesiveness in the text itself. The use of the lexical item like superordinate and collocation helps cohesiveness in the text. 


\section{References}

Anonim. Hospitality Industry. http://essay-samples.blogspot.co.id.

(Accessed in November, $21^{\text {th }}$ 2017)

Anonim. Importance of Education. http://www.editorialfragua.com (Accessed in November, 21th2017)

Atul Joshi. Food.

http://www.preservearticles.com

(Accessed in November, 21th 2017)

Halliday, M.A.K. and Hasan, R. 1976.

Cohesion in English. London: Longman group Ltd

Sanjran Gichki. Internet. https://sanjran.wordpress.com/essay-oninternet/. (Accessed in November, 21th 2017) 